\title{
ACTING PLAY SCRIPT: A TECHNIQUE TO IMPROVE SPEAKING SKILLS THROUGH ENGLISH DRAMA FOR NON-ENGLISH DEPARTMENT STUDENTS \\ A Case Study Of The First Semester Students Of Islamic Guidance And Counseling Major Of IAIN Surakarta
}

\author{
Yetty Faridatul Ulfah \\ IIM Surakarta \\ zetyfu@gmail.com
}

\begin{abstract}
Abstrak
Penelitian ini bertujuan untuk (1) mengetahui apakah teknik Acting Play Script (APS) dapat meningkatkan kemampuan berbicara bahasa Inggris mahasiswa; (2) menggambarkan sejauh mana teknik APS dapat meningkatkan kemampuan berbicara bahasa Inggris mahasiswa; dan (3) menggambarkan respon mahasiswa terhadap penerapan teknik APS. Penelitian ini merupakan penelitian tindakan kelas mata kuliah Bahasa Inggris untuk meningkatkan kemampuan berbicara Bahasa Inggris dengan teknik APS yang dilaksanakan bulan September sampai Desember 2018 di IAIN Surakarta dengan subject penelitian mahasiswa semester I jurusan Bimbingan Konseling Islam, Fakultas Da'wah IAIN Surakarta, Tahun akademik 2018/2019. Penelitian ini menggunakan pendekatan kualitatif dan kuantitatif. Data kuantitatif dianalisis menggunakan statistic deskriptif. Sementara data kualitatif menggunakan teknik Constant-comparative oleh Strauss and Glasser. Hasil penelitian ini menunjukkan: (1) Penggunaan teknik APS dalam drama bahasa Inggris dapat membantu siswa dalam meningkatkan kemampuan berbicara bahasa inggris mahasiswa; (2) APS dapat meningkatkan kemampuan berbicara bahasa inggris mahasiswa dalam hal: peningkatan prestasi dalam berbicara bahasa Inggris; $b$. peningkatkan kemampuan mahasiswa dalam mengekspresikan ide-ide dalam bentuk grammar dan kosa kata; dan meningkatkan pelafalan bahasa Inggris yang benar; (3) Respon mahasiswa terhdapan teknik APS pada kelas speaking adalah positif karena APS itu menyenangkan, menarik dan menantang. APS memberikan motivasi yang bagus dan meningkatkan semangangat para mahasiswa, jadi mereka termotivasi untuk berbicara bahasa Inggris.

Kata Kunci: Teknik APS, Kemampuan berbicara, Drama bahasa Inggris
\end{abstract}

\section{Introduction}

Language acquisition is considered successful if someone can demonstrate his/her ability to speak in the target language (Brown \& Yule, 1997: 267). Therefore, it is essential that the teaching of English be directed to achieve speaking skill. The aim of teaching speaking in English is to train students to be 
able to express meaningful and contextual communications in English as in real life. In other words, most students may express ideas or opinions in transactional and interpersonal communication which becomes the most important aspect of learning a foreign language like English. Thus, in classroom setting, the learner's success in learning English should be measured in terms of their ability to converse or to speak in English. That is why discussion, question and answer, drama, games, and role play are recommended in the classroom teaching learning activities.

In speaking class, teachers are required to create communicative and interactive activities by giving students a great deal of opportunities to practice the target language (Achmad \& Yusuf, 2014: 151). Acting Play Script (APS) is one of the teaching speaking techniques in which the students have to act out the short written sketches or scenes in group of two, three or four. They have to create their scripts based on the topic given, memorize it and at last they have to act their scripts out in front of the class. Thus, the scripts have important role as they depict the students' ideas, also represent their speaking skill. In scripts there is language value. Scripts provide a rich source of comprehensible input in language that is natural and spoken (Dougil, 1987: 22).

Speaking is one of skills of English subject thought for non-English department students at university, including the first semester students of Islamic guidance and counseling major of IAIN Surakarta that achieve English as a compulsory course. One way to improve speaking ability among the students is through English drama applying APS technique. Some problems are found during this skill learning. Thus, the researcher chooses the Classroom Action Research to improve and solve the students speaking problem in the first semester of Islamic guidance and counseling major of IAIN Surakarta. The problems occurred in speaking learning among the first semester students of Islamic guidance and counseling major of IAIN Surakarta are due to the following indicators; (1) most of the students have limited vocabularies in expressing some ideas using English; (2) some students have difficulties to arrange words in English; (3) the students have problems in pronouncing the words correctly and speaking in a proper 
intonation; (4) the students neither achieve fluency nor accuracy in speaking English; (5) the students sometimes have some errors to write some words in English.

APS technique, moreover, is suitable with the characteristics of successful speaking activity referring the characters of learners in talking a lot, as much as possible. Learners are also eager to speak because they are interested in the topic and have something new to say about it, and language is of an acceptable level learners express themselves in utterances that are relevant, easily comprehensible to each other, and of an acceptable level of language accuracy. Indeed, by applying APS technique, the students can work in groups in which they can discuss the problems together. In other words, they have enough time to write the scripts in which the students can discuss about the choice of words, the grammar, and the intonation to perform their scripts. APS technique also can change the passiveness of the students in the classroom activities directly into an active learning and trigger the students to interact fluently each other in the target language.

\section{Speaking Skill}

Speaking defines as the ability of using the language orally which plays crucial role in learning and understanding the target language. Most of speaking activities are in the form of face-to-face dialogue. Nunan (1991: 390) states that mastering the art of speaking is the single most important aspect of learning a second or foreign language, and success is measured in term of the ability to carry out a conversation in the language (Nunan, 1991: 390). However, some university students of non-English department have difficulties in speaking using English; even they have been learning it since their study at elementary school. Aleksandrzk (2011: 38) argues that to achieve proficiency in foreign language speaking in classroom conditions is not an easy task. Even advanced learners often finish a language course with the conviction that they are not sufficiently prepared for speaking beyond the classroom. This difficulty results basically from the character and inadequate frequency of speaking opportunities in the classroom 
in comparison to the abundance of natural varieties and genres of oral communication (Magdalena, 2008: 11).

Spoken English has different characteristics with the written form. As pointed out by Harmer (1998: 49) that several characteristics of English as spoken language, as follows: first, people speak in incomplete sentence. Second, speakers must repeat what each other says. Third, speakers tend to apply contractions (Jeremy, 1998: 49). Additionally, Thornburry (2005: 4) proposes basic knowledge that enabling speech in a second language, they are: (1) a core grammar, (2) a core vocabulary of at least 1000 high frequency items, some common discourse markers, (3) a core "phrase book" of multi-word units (chunks), (4) formulaic ways of performing common speech acts, such as requesting or, (5) inviting, (6) mastery of those features of pronunciation that inhabit intelligibility (Thornbury, 2007: 4).

From the above definitions, it can be concluded that there are some aspects of speaking skill must be considerate, i.e. pronunciation, grammar, vocabulary, fluency and comprehension. Moreover, the teacher must give opportunities to the students to respond to a given topic and provide the time for them to practice. It also helps the students become easy to speak and more interested in learning and speaking English. If the students do not get any opportunity to communicate in the language classroom, otherwise, they are not motivated and lose interests in the learning process.

\section{English Drama as one of Speaking Activities in Language Learning}

According to Yusnani Lubis (in Suharno, 1998: 27), there are fourteen types of communicative activities. One of them is drama. Drama is a more formalized form of role-play, with a preplanned story line and script. Sometimes small groups may prepare their own short dramatization of some even, writing the script and rehearsing the scene as a group. This may be more commonly referredto as a "skit". Longer more involved dramatic performances have been shown to have positive effects on language learning, but they are time consuming and rarelycan form part of a typical school curriculum (SUharno, 2007: 27). 
Moreover, drama also has an important role for the students to encourage them in speaking English. As Ulas (2008: 876-880) comments, although drama has existed as a potential language teaching tool for hundreds of years it has only been in the last thirty years or so that its applicability as a language learning technique to improve oral skills has come to the forefront (Ulas, 2008: 879). In line with this, Zyoud (2011: 163) argues that teaching English as a foreign language inevitably involves a balance between receptive and productive skills; here drama can effectively deal with this requirement. It also can foster and maintain students' motivation, by providing an atmosphere which is full of fun and entertainment. In so doing, it engages feelings and attention and enriches the learners' experience of the language (Zyaoud, 2011: 163).

The numerous benefits of drama in language teaching stated by Maley and Duff (2005: 139) are:

a. It integrates language skills in a natural way. Spontaneous verbal expression is integral to most of the activities.

b. It integrates verbal and non-verbal communication

c. It draws upon both cognitive and affective domains.

d. By fully contextualizing the language, it brings the classroom interaction to life through an intense focus on meaning.

e. The emphasis on whole-person learning and multi-sensory inputs helps learners to capitalize on their strength and to extend their range.

f. There is a transfer of responsibility for learning from teacher to learners which is where it belongs (Duff, 1982: 139).

Based on the principle above, drama has criteria as a method to teach speaking. It is very helpful to trigger the students' ability in speaking English involving their own thinking and creativity. Drama encourages the students to actively participate in teaching learning English process because it provides a way of creating a rich communicative environment where the students actively become a part of some real word system. It can also increase self confidence of hesitant students, because the students will have different role and responsibility. 


\section{Acting Play Script as a Technique to Improve the Students' Ability in Speaking English}

Acting Play Script (APS) is short written sketches or scenes which are acted out by the students in front of the class. It is an excellent way to get students to use the language. It essentially involves using the imagination to make oneself into another character, or the classroom into a different place. It can be a starting point for exciting listening and speaking work and it can be utilized as a tool to provide practice in specific grammatical, lexical, functional or phonological areas (Scrivener, 1994: 69).

Furthermore, Scrivener also states that bringing the outside world into the classroom in this way we can provide a lot of useful practice (in cafes, shops, banks, streets, zoos, parties, etc.) that would otherwise impossible. There can also be a freeing from the constraints of culture and expected behavior; this can be personally and linguistically very liberating. Curiously, it is sometimes the shyest students who are most able to seize the potential (Scrivener, 1994: 69). In other words, it is helpful for the students to have tried out and experimented with the language they will require in the friendly and safe environment of a classroom. For these students, APS is very useful dress rehearsal for real life. It enables them not only to acquire set phrases, but also to learn how interaction might take place in variety of situations.

Moreover, some guidelines of applying APS technique are also depicted by Scrivener. The steps are as follows:

a. The students should understand the idea of APS

b. The situation should be clear.

c. The students are allowed to write the scripts in the right structure, to let them open the dictionary to find the proper words, and also to give time to memorize the scripts.

d. The students are given the time to prepare their ideas before the speaking starts

e. When the activity of speaking starts, the students are encouraged to improve rather than rely on prepared scripts (Scrivener, 1994: 70). 
It can be concluded that APS can improve the learners' speaking skill in any situation, and help the learners to interact. It is because APS gives natural context for using target language in the classroom. There are a lot of chances for the students to interact in English in acting the plays. Besides, it encourages students' active learning. It is also motivated and familiar to the students for the choice of the material can be adapted to students' interests as well as the real world need. As for the shy learners, APS help by providing a mask, where learners with the difficulty in conversation are liberated. Some more shy members of a group may have a great deal of difficulty participating in conversation about themselves, and in other activities based on their direct experience. These studentsare deliberated by APS as they no longer feel that their own personality is involved. In addition, it is fun and most learners will agree that enjoyment leads to better learning.

\section{Research Method}

This research was carried out at IAIN Surakarta; the subjects of this research were the first semester of class B students consisting of 34 students of Islamic guidance and counseling major of Da'wah faculty in the academic year of 2018/2019. The writer made 6 groups for drama consists of 5 until 6 students in one group. The reason why the researcher took them as subjects is because someof them have lack ability in speaking English although they had learnt it since they were in junior high school.

This research applied Classroom Action Research (CAR) design beginning with planning, implementing the plan, observing the implementation, and reflecting or evaluating the process and the result of the implementation. This procedure was adopted from Mills. Furthermore, Mills defines that CAR has the potential to be a powerful agent of educational change. For English learning, CAR aims at discovering learning-teaching strategies that match learners' style and strategies in learning English. CAR may be done in several cycles each of whichis repeated in the next cycle if the result is not satisfactory yet with the better revised lesson plan (Mills, 2003: 5). 
Qualitative and quantitative data were collected in this research. The qualitative data were analyzed using constant-comparative technique proposed by Strauss and Glasser. There are four steps in this method, i.e. comparing incidents applicable to each category, integrating categories and their properties, delimiting the theory, and writing the theory (Glaser \& Strauss, 1980: 105). In finding qualitative data, the researcher will do direct observation in the classroom, give questionnaire, and interview the students. Meanwhile, the quantitative data were found by conducting pre-test and post-test. The quantitative data were analyzed using descriptive statistic, finding out the mean of the scores in the test and the improvement of the students' scores during the research. In this study, the researcher uses an analytical rating score. The scoring rubric of speaking test is adapted from Hughes (Hughes, 2003: 131).

Table 1

Criteria of Speaking Proficiency

Student's action

Scale

of score

(1) Pronunciation frequently unintelligible, (2) Grammar almost entirely inaccurate in stock phrases, (3) Vocabulary inadequate for even the simplest conversation, (4) Speech is too halting and fragmentary that conversation is virtually impossible, (5) Understand too little for the simplest type of conversation

(1) Frequent gross errors and very heavy accent make. Understanding difficult, require frequent repetition, (2) Constant errors showing control of very few major patterns and frequently preventing communication, (3) Constant limited to basic personal and survival areas (time, food, transportation, family, etc), (4) Speech is very slow and uneven except for short or routine sentences, (5) Understand only show, very simple speech on common social and touristic topic; requires constant repetition and rephrasing

(1) "Foreign accent" requires concentrated listening, and mispronunciation lead to occasional misunderstanding. Apparent errors in grammar and vocabulary, (2) Frequent errors showing some major pattern uncontrolled and causing occasional irritation and misunderstanding, (3) Choice of words sometimes inaccurate, limitations of vocabulary, prevent discussion 
of some common professional and social topic, (4) Speech is frequently hesitant and jerky; sentences may be left uncompleted, (5) Understand careful, somewhat simplified speech when engaged in a dialogue, but may require considerable repetition and rephrasing

(1) Marked "Foreign accent" and occasional mispronunciation which do not interfere with misunderstanding, (2) Occasional errors showing imperfect control of some pattern but no weakness that causes misunderstanding, (3) Professional vocabulary adequate to discuss special interests; general vocabulary permits discussion of any non-technical subject with some circumlocutions, (4) Speech is occasionally hesitant, with some unevenness caused by rephrasing and grouping for words, (5) Understand quite well normal educated speech when engaged in a dialogue, but requires occasional repetition or rephrasing

(1) No conspicuous mispronunciations, but would not be taken for a native speaker, (2) Few errors, with no pattern of failure, (3) Professional vocabulary broad and precise; general vocabulary adequate to cope with complex practical problems and varied social situation, (4) Speech is effortless and smooth, but perceptively non native in speed and evenness, (5) Understand everything in normal educated conversation except for very colloquial or low-frequency items, or exceptionally rapid or slurred speech

(1) Native pronunciation, with no trace of "Foreign accent", (2) No more than errors during the interview, (3) 10,0 Vocabulary apparently as accurate and extensive as that of an educated native speaker, (4) Speech on all professional and general topics as effortless and smooth as a native speakers', (5) Understand everything in both formal and colloquial speech to be expected of an educated native speaker

\section{(Adapted from Hughes)}

Note:

(1). Pronunciation proficiency

(2). Grammar proficiency

(3). Vocabulary proficiency

(4). Fluency proficiency

(5). Comprehension proficiency 


\section{RESEARCH RESULT}

\section{Pre-research Stage}

Pre-research stage was an act to determine the situation before the research. It was conducted to identify the students' ability in speaking English. In this stage, the students were asked to make a short dialogue with one-self personality theme. The theme was chosen to measure their basic skill of speaking English considering that they had been learning it since they were in Primary School. They should, then, practice the dialogue in front of the class by memorizing it. Unfortunately, the result of pre-test showed that the students had low ability in speaking proven by the low achievement of speaking test. The meanscore of the preliminary test was 61.5.

\section{Students' Perception on Speaking}

In-depth interview was applied to determine and to explore the students' perception on speaking. Besides, the students were also asked to fill the questionnaire to support the data. The results of interview can be seen in table 3 below.

Table 2

Results of Interview

\begin{tabular}{|c|c|c|c|}
\hline \multirow[b]{2}{*}{ o. } & \multirow[t]{2}{*}{ Questions } & \multicolumn{2}{|c|}{ Students' Response } \\
\hline & & $\overline{\text { Yes }}$ & No \\
\hline . & $\begin{array}{l}\text { Do you like English } \\
\text { subject? }\end{array}$ & $94 \%$ & $6 \%$ \\
\hline - & $\begin{array}{l}\text { Is English important } \\
\text { for your major? }\end{array}$ & $100 \%$ & $0 \%$ \\
\hline . & $\begin{array}{l}\text { Do you like speaking } \\
\text { class? }\end{array}$ & $79 \%$ & $21 \%$ \\
\hline & $\begin{array}{ccc}\text { Can } & \text { you } & \text { speak } \\
\text { English? } & & \\
\end{array}$ & $6 \%$ & $94 \%$ \\
\hline & Is speaking difficult? & $94 \%$ & $6 \%$ \\
\hline
\end{tabular}

Meanwhile, the questionnaire was employed to determine the problems of speaking difficulties faced by the students. The most difficult problem in speaking class is grammar followed by vocabulary, pronunciation. They thought that they 
did not need to learn sentence pattern in arranging sentences. Learning speaking means speaking directly without structure. They did not realize that without studying sentence pattern they would not be able to arrange the words. So they did not practice to arrange sentences frequently. The other factors became the lowest percentage. These factors included psychological barriers, such as shyness, the fear of making mistakes, the fear of being humiliated and lack of confidence. Table 4 below represents the problems of speaking difficulties.

Table 3

Problems of speaking Difficulties

\begin{tabular}{|c|c|c|}
\hline o. & $\begin{array}{lll}\begin{array}{c}\text { Problems } \\
\text { difficulties }\end{array} & \text { of } & \text { speaking } \\
\end{array}$ & Percentage \\
\hline & Grammar & $40 \%$ \\
\hline & Vocabulary & $30 \%$ \\
\hline & Pronunciation & $20 \%$ \\
\hline & Others & $10 \%$ \\
\hline
\end{tabular}

\section{First Cycle}

The first cycle was conducted in three meetings; on $4^{\text {th }}, 11^{\text {th }}$ and $18^{\text {th }}$ of September 2018. In the first cycle the researcher introduced to the students about the technique of APS in teaching speaking, the purpose of APS and the use of APS for the students in improving their speaking skill.

In the second meeting, the researcher grouped the students into six groups to which one topic was given to each group. The topics were about transportation, lifestyle changes, traveling, modern technology, holidays, and childhood memories. The students should make a script based on the topics in short time and then performed it in front of the class. In the last meeting of the first cycle, the assessment of speaking ability was held by the researcher. The mean score of the first cycle can be seen in Diagram 1.

\section{Reflection}


In conducting this action research, the researcher cast a role as the teacher to present APS in English drama for teaching speaking. From the observation result, the researcher revealed that some students mostly produced many errors in grammar. However, the use of APS technique was quite effective in teaching speaking. It motivated the students to speak English. It was proved with the students talking a lot during the discussion and the play. They were also able to change the atmosphere of the classroom into a more relaxed and cheerful. The students seemed enjoy getting along and interacting among each others. Theresearcher also noticed the students whose English ability was low seemed enthusiastic to join the play. They had a satisfaction of achievement feeling because they could speak English like the students whose English's ability was better.

Table Diagram 1

The Score of Cycle 1

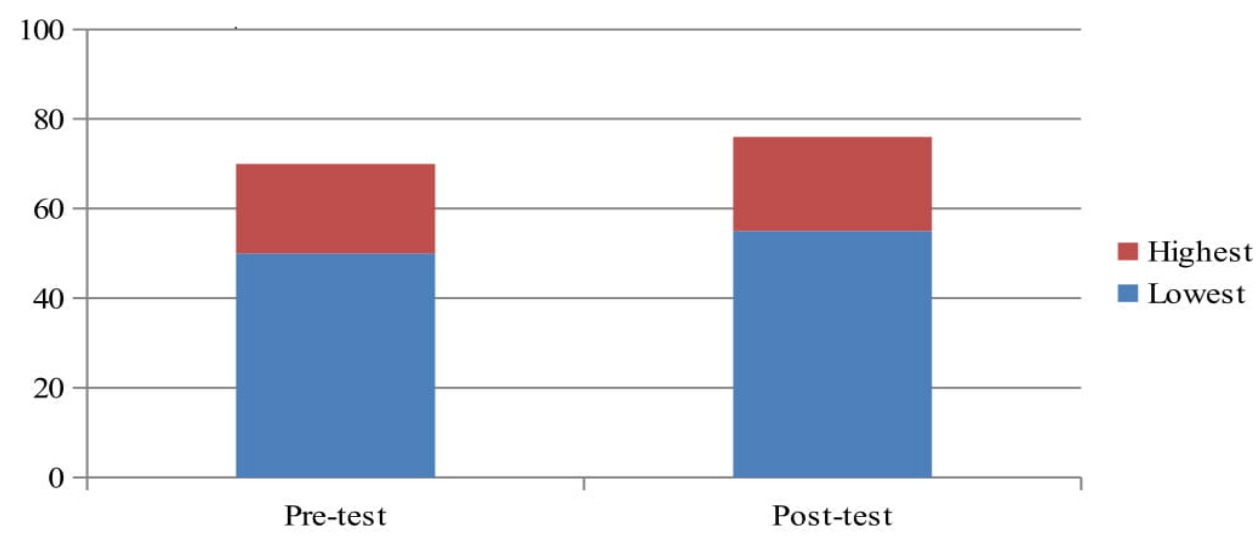

Moreover, the researcher also agreed that APS was a technique that gave chances for the students to improve their competence in speaking skill by providing activities which used English to interact among them in interpersonal or transactional communication and could improve the students' ability in pronunciation, grammar, vocabulary, fluency, and comprehension. It can be seen from the table above that reveal the lowest score of pre-test was 50 and the highest score was 70, so the mean score of pre-test was 61.5. Whereas the lowest score of post-test was 55 and the highest score was 76, so the mean score of post- test was 65.5 . 


\section{Second Cycle}

The second cycle was also held in three meetings; on $6^{\text {th }}, 13^{\text {th }}$, and $20^{\text {th }}$ of November 2018. The concept of APS was to teach the students to speak English in meaningful activities in order to produce a speaking which looks like a real conversation. Based on the first cycle results, the researcher revised some aspects of the learning to achieve better results in the second cycle.

The application of APS technique was conducted by giving one topic to each group to play English drama related to their major study, Islamic counseling, and this was given to the students in the second meeting. The topics were about divorce, child adoption, pre-wedding consultation, conflict in the office, drugs addicted, and juvenile delinquency. The students were then asked to discuss, to write the script of drama and to divide roles based on their characters.

In the last meeting of the second cycle, the students performed the play in outside the class. The activities were conducted in the park of the campus. The park was very wide, clean and shady, so that the students could express their play freely. After the students finished their performance, the teacher did an evaluation by giving some comments towards what they had already done. In this case, the focus of the teacher's comments was on those five aspects of speaking. The students were also asked to fill the questionnaire discussing about their responses toward the application of APS technique through English Drama. Most of them were excited to apply APS technique in speaking English.

\section{Reflection}

Some revisions have been implemented in the second cycle. In this cycle, the researcher revealed some improvements in the students' ability of speaking. The researcher found that the students seemed more enthusiasm and confident to involve in the drama and to play their roles out of their real character. The students were also very vigorous to share their difficulties or problems in some aspects of language such as pronunciation, grammar, and vocabulary. They could correct their mistakes one another, so that it was beneficial to improve their 
grammar, pronunciation and vocabulary when the oral production should be performed. The improvements were also proved by the score achieved. Below is the diagram showing the result of pre-test and post-test in the second cycle.

Table Diagram 2

The Score of Cycle 2

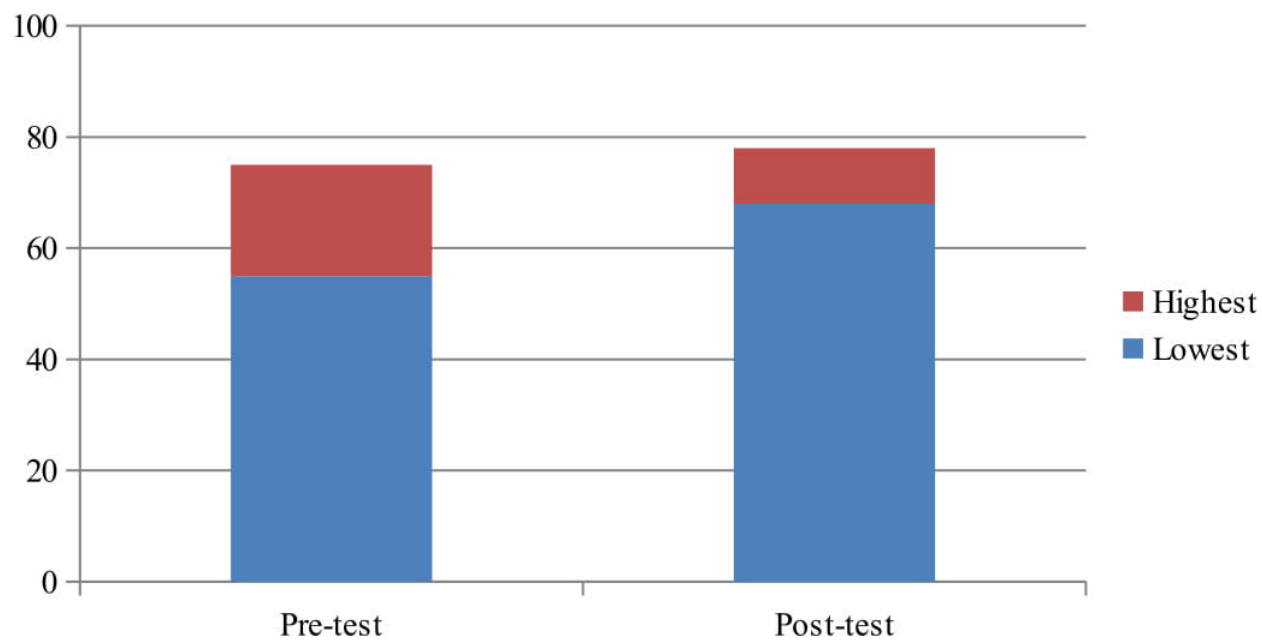

The data shows that the average score in cycle 2 is more satisfying than the first one. It can be seen that the minimum score of post test gained by the students is 68 and the maximum score is 78. And it can be proved that the averagescore of pre-test is 60 and the average score of the post-test in the second cycle is 69. It means that APS technique can increase students' ability in speaking.

Meanwhile, the result of the questionnaire indicates that $100 \%$ percent of students agreed to learn English speaking by applying APS technique. Most of them argue that they can have group discussion during APS activity. They are also motivated to speak English by using the APS technique, especially in English drama. The APS technique, indeed, can make any improvement in their speaking ability. In conclusion, the students definitely agree to employ APS technique in speaking class.

\section{Observation Result}

In this study, the researcher also did observation. During the first and the second cycle, especially in the process of teaching and learning, the researcher 
acted as the lecturer. Here, the observation was filled out by the researcher who acted as an English lecturer at Islamic guidance and counseling major of Da'wah faculty of IAIN Surakarta.

At the first cycle, in pre activity, the researcher made brainstorming related to the topic (hobby) by asking few simple questions such as: What is your hobby? How often do you do your hobby? Why do you like your hobby? Through these questions, the observer could come up students' background knowledge about the given topic. The reason behind it because the students were familiar with the topic, could identify and answer the particular questions. Even though they were more likely lack of confidence in delivering their own ideas or opinions and still worked individually in delivering their ideas. At the second cycle, in pre activity, the researcher made some evaluation to check students understanding of the previous lessons and also made brainstorming related to the new interesting topic (holiday) by asking few simple questions. Through this moment, the observer pointed out that the teacher had good intention to flashback students' deep understanding about previous materials and continued the learning process by creating new questions for the students.

Based on the result of observation and tests, there was an improvement in students' speaking ability. The improvement could be recognized from the improved achievement from cycle to cycle. Besides, the improvement in speech features could also be noticed. The improvement was the fluency and accuracy of speech was achieved. Besides, it was revealed that there were bigger chances for the students to act their scripts in a play, in which they could train their pronunciation and intonation as well. They also could choose the location for their presentation to be more alive. Teacher was more innovative in teaching speaking, and in trying all efforts to explore students' potentials in speaking.

\section{Discussions}

The success of the students in developing their speaking abilities occurred when students were able to deliver ideas in their minds based on the given topic. By choosing an interesting topic, students enjoyed exploring what they really 
thought about something much deeper. APS, which was applied in this research to improve students' speaking achievement, has successfully brought improvement in the students' speaking ability. However, there should be a high effort from boththe teacher and the students to make the students capable to speak in every cycle by using their own opinion. This study was conducted to answer the research questions. So, the following sections will be discussing on how APS technique could improve students' speaking abilities as well as describing how students' perceptions on this technique implementation.

\section{The Improvement of Students' Speaking Ability Applying Acting Play Scripts Activity}

It is found that APS technique can improve the students' speaking ability in terms of students' achievement. The improvement could be achieved because APS provides better opportunities for language learning to take place. APS is also beneficial to develop learning strategy which consists of discussion and performance sections. In discussion section, the students discuss the topic, select the appropriate vocabulary and also tenses which could be used. And at last, they compose the scripts from the data they gathered. When they have finished, they have to make sure that there is no mistakes on their scripts. They look up their dictionary to find the pronunciation of the new words, sometimes; they ask their friends or even the teacher. They memorize their part of their scripts and perform it in front of the class. Having strong underlying education theory, it is not surprising that APS is beneficial in improving students' achievement.

Moreover, APS technique also develops the students' ability to express ideas using appropriate vocabulary and grammatical form. In APS activity, there are three stages the students have to do, namely vocabulary and language focus, composing the scripts and action. From those steps, we can see that building vocabulary becomes the crucial parts of a task, and it is placed at the very beginning steps; whereas grammatical form is also given sufficient portion, but itis placed after choosing related vocabularies. 
Other improvement that APS technique can reveal is to help the students in developing their pronunciation considered as a basic knowledge in speaking. This means that if the script given to the students to be read aloud by a group, opportunities for characterization, and changes of mood and pronunciation work will arise. The only role for the teacher is providing enough practice of the knowledge that will help the students in communicating in real-life situation.

\section{The Students' Responses after the Application of APS Technique}

Besides the test, the questionnaire and observation results proved that the students' responses were positive toward APS technique in the learning process. From the students' responses to the questionnaire, the researcher found that most of students were easy to learn speaking through the implementation of this technique. Most students agreed to use APS as a technique in learning speaking. The reasons were because APS was fun, interesting, exciting and challenging. APS made the lesson easier to understand, and APS could be a good facility in leaning speaking. APS gave good motivations and raised the spirit of the students. The activity encouraged the students to speak. The students were curious about the activities so they wanted to learn more and more. APS improved not only students' vocabulary and grammar but also pronunciation, comprehension, and fluency.

Indeed, the students were motivated to learn speaking with APS. The reasons were because APS was very enjoyable and challenging. The students found that speaking was not something difficult, therefore they were eager to do the activity. The students admitted that group work was really a perfect method to share with their friends, solve their problems, take and give to each other. Now, speaking is no longer becoming a big problem for them. Before the implementation of APS, speaking activity was a big burden for the students. They even felt that the enjoyment of the activities made the students do the tasks in full of spirit. 


\section{Conclusion}

The main purpose of this research is to find out the improvement in speaking ability by applying APS technique for non-English department students. The results show that students speaking abilities has improved. The improvement of students' speaking ability can be identified from the improvement of speaking achievement, students' ability in expressing ideas using appropriate vocabularies and grammatical forms, and students' ability to develop pronunciation. The problems from the students that the researcher encountered after evaluation in the first cycle could be improved in the second cycle. The students' scores in the first cycle increased rapidly in the second cycle. Based on the questionnaire results, APS activity also provided positive effect to the students. They agreed and expected the implementation of APS activity to improve their speaking abilities in the teaching and learning process of English subject. Therefore, it can be concluded that this technique was successful in improving students speaking abilities for the first semester students of Islamic Guidance and Counseling major of Da'wah faculty of IAIN Surakarta.

\section{Bibliography}

Achmad, D. \& Yusuf, Y. Q. 2014. Observing Pair-work in An English Speaking Class. International Journal of Instruction. Vol.7 No. 1. January 2014.

Aleksandrzk, Magdalena. 2011. Problems and Challenges in Teaching and Learning Speaking at Advanced Level. Glottodidactica xxxvii. Adam Mickiewicz University Press Poznań.

Brown, Gillia \& Yule, George. 1997, Teaching the Spoken Language. Cambridge: Cambridge University Press.

Dougil, John. 1987. Drama Activities for Language Learning . MacmillanPublisher LTD. London and Basingstoke.

Glaser, B., and Strauss, A. 1980. The Discovery of Grounded Theory. Chicago: Aldine.

Harmer, Jeremy. 1998. How to Teach English: An introduction to the practice of English language teaching. Longman: Wesley Longman.

Hughes, Rebbeca. 2003. Teaching and Researching Speaking . London: Pearson Education 
Maley, A. and Duff, A. 1982. Drama Techniques in Language Learning. Cambridge: Cambridge University Press.

Mills, Geoffrey E. 2003. Action Research: A Guide for the Teacher Researcher. New Jersey: Prentice Hall.

Nunan, David. 1991b.Language Teaching Methodology: A Textbook for Teacher. New York: Prentice-Hall.

Scrivener, Jim. 1994. Learning Teaching: A guidebook for English Language Teachers. Macmillan - Heinemann, English Language Teaching (ELT)Oxford. A division of Macmillan Publishers Limited

Suharno. 2007. Improving students' English Speaking Using Role Play. Surakarta: Unpublished English Education Magister Thesis of Sebelas Maret University, Surakarta

Thornbury, S. 2007. How to Teach Speaking. Harlow: Pearson Education Limited

Ulas, A. H. 2008. Effects of Creative, Educational Drama Activities on Developing Oral Skills in Primary School Children. American Journal of Applied Sciences. Vol. 5 No. 7

Zyoud, M. 2011. Using Drama Activities and Techniques to Foster Teaching English as a Foreign Language: A Theoretical Perspective. Al Quds Open University 